\title{
Response of false broomweed and associated herbaceous species to fire
}

HERMAN S. MAYEUX, JR., AND WAYNE T. HAMILTON

\section{Abutract}

Foliar cover of the shrub false broomweed (Ericamerla custrotexana M.C. Johnston) was reduced 45 to $65 \%$ at the end of the first post-burn growing reason and by an average of $29 \%$ at 4 years after controlled burning in August. False broomweed's response to February burns was more variable, ranging from 36 to $77 \%$ canopy reduction after the first growing season and 3 to $54 \%$ after 4 years. Burning in August or February temporarily decreased standing crop of the most common bunchyrasses, pink pappiagrusa (Pappophorum bicolor Fourn.) and whiplash pappusgrass (P. mucromulatuon Nees.), without influencing frequency of oceurrence, indicating that fire reduced vigor of these grasses. Total end-of-season standing crop reflected reductions in pappusgrass production. Fire tended to favor or had no effect on other bunchgrasses, and generally cuppressed frequency and standing crop of undesirable grasses such as red grama (Boutelowa trifida Thurb.). Burning in either season had little effect on common curlymesquite [Hilarta berlangeri (Steud.) Nash].

Key Words: Ericameria austrotexana, common curlymesquite, pappuseraes

Fire is as an economical method of suppressing woody species and enhancing forage availability and utilization. Controlled fire alone provides only temporary and partial suppression of the resprouting brush species characteristic of south Texas (Hamilton and Scifres 1982), but fire readily fits into brush management systems designed to provide long-term suppression of woody species (Scifres 1980).

False broomweed (Ericameria austrotexana M.C. Johnston) is one of several small, multistemmed shrubs which interfere with forage production on grasslands interspersed within the brush on the Rio Grande Plains and adjacent Coastal Prairie. It resprouts readily after mechanical control treatments or other disturbance. False broomweed is not controlled by herbicides normally used on rangelands as sprays, but carrying capacity was almost doubled when the shrub was controlled with the non-selective herbicide glyphosate ( $N$-phosphonomethyl glycine) (Mayeux et al. 1980). Aerial applications of picloram (4-amino-3,5,6-trichloropicolinic acid) and tebuthiuron $\{N-[5-(1,1-$ dimethylethyl)-1,3,4-thiadiazol2-yl]- $N, N$-dimethylurea\} pellets were also effective (Mayeux and Chamrad 1982). Picloram reduced density of the dominant grass species, common curlymesquite [Hilaria berlangeri (Steud.) Nash], but had little effect on other components of the herbaceous vegetation. Density of common curlymesquite increased substantially at the expense of annual and short-lived perennial grasses and forbs where tebuthiuron was applied for control of false broomweed (Mayeux and Chamrad 1982).

Fire has potential for use in management of rangeland dominated by other shrubs which are closely related to false broomweed and are also resistent to other control practices. Burning during winter in south Texas reduced density of common goldenweed [Isocoma coronopifolia (Gray) Greene] by 33 to $44 \%$ and sup-

\footnotetext{
Authors are range scientist, USDA, Agricultural Research Service, P.O. Box 6112, Temple. Texas 76503-6112, and senior lecturer, Texas Agricultural Experiment Station, Department of Range Science, Texas A\&M University, College Station 77843. This article is published with the approval of the Director, Texas Agricultural Experiment Station, as TA 22548.

the authors acknowled ge the technical assistance provided by R.A. Crane and T.R. Neidlinger. Access to land and other assistance was provided by Chester Kiefer. The research was partially funded by USDA, CSRS Special Grant 810-15-28.

Manuscript accepted 6 August 1987
}

pressed canopy cover and height of survivors for 2 years (Mayeux and Hamilton 1983). Fire did not reduce density of the associated buffelgrass (Cenchrus ciliaris L.), but caused slight and temporary increases in standing crop. Burning during late winter removed 18 to $41 \%$ of the rayless goldenrod [Isocoma wrightii (Gray) Rydb.] plants growing on native rangeland in west Texas (Ueckert et al. 1983).

The objectives of this study were to evaluate the effectiveness of single controlled fires in summer and winter for suppression of false broomweed, and to assess the effects of fire on the composition and productivity of associated herbaceous plants. Grasslands vary widely in the nature and extent of their response to fire (Vogl 1974, Wright and Bailey 1982), exhibiting responses similar to those caused by herbicides and mechanical treatments in some plant communities (Scifres 1980). An understanding of these responses is basic to the evaluation of fire as a brush management practice.

\section{Methods}

\section{Site Description}

Experimental burns were conducted on a rolling hardland range site near Batesville, Texas, in the northwest corner of the Rio Grande Plains. The area is semiarid, with warm winters, extended periods of high temperatures in summer, and a growing season of about 280 days. Average annual rainfall is $52 \mathrm{~cm}$, with most rains occurring in spring months. Little rainfall is recorded in summer, and herbaceous vegetation is often dormant in late summer. The site was grazed by cows and calves and occasionally by mohair goats at $1 \mathrm{AU} / 7$ ha for 8 months from early spring to late fall until all grazing was excluded 1 year before the study was begun. Soils were saline Maverick clay loams (Ustollic Camborthids).

Scattered honey mesquite [Prosopis juliflora var. glandulosa (Torr.) Cockerell], blackbrush acacia (Acacia rigidula Benth.), and spiny hackberry (Celtis pallida Torr.) occurred at the site, but the area was dominated by a mature stand of false broomweed which varied in density and foliar cover across the site. Herbaceous vegetation consisted of areas occupied by the stoloniferous, sodforming shortgrass common curlymesquite interspersed within a midgrass community of warm-season perennial bunchgrasses. The more important and desirable of these were pink pappusgrass (Pappophorum bicolor Foum.), whiplash pappusgrass (P. mucronulatum Nees.), two-flower trichloris [Trichloris crinata (Lag.) Parodi], Texas bristlegrass (Setaria texana Emery), white tridens [Tridens albescens (Vasey) Woot. \& Standl.], the introduced King Range bluestem (Andropogon ischaemum L. var. songaricus Rupr.), and Hall's panicum (Panicum hallii Vasey var. hallii). Less valuable perennials included purple threeawn (Aristida purpurea Nutt.), red grama (Bouteloua trifida Thurb.), and whorled dropseed [Sporobolus pyramidatus (Lam.) Hitch.]. Almost no annual or cool-season grasses were present. Forbs occurring on the site were smallhead sneezewead (Helenium microcephalum DC.), dogweed [Dyssodia tenuiloba (DC.) Robins], purslanes (Portulaca oleracea L. and P. retusa Engelm.), a mat spurge (Euphorbia sp.), bundleflower (Desmanthus virgatus L.), globemallow (Sphaeralcea sp.), wild petunia (Ruellia sp.), false ragweed (Parthenium confertum Gray), and prairie tea (Croton monanthogynus Michx.).

Burning and Sampling Procedures

Headfires were applied to duplicate 1-ha plots $(92$ by $110 \mathrm{~m})$ in 
Table 1. Weather and fuel conditions during controlled burning of native nugeland dombated by falue broomweed new Bateaville, Texas.

\begin{tabular}{|c|c|c|c|c|c|c|c|c|}
\hline \multirow[b]{2}{*}{ Burn date } & \multirow{2}{*}{$\begin{array}{l}\text { Air temp. } \\
\text { (C) }\end{array}$} & \multirow{2}{*}{$\begin{array}{c}\text { Relative } \\
\text { humidity } \\
(\%)\end{array}$} & \multirow{2}{*}{$\begin{array}{c}\text { Wind } \\
\text { speed } \\
(\mathrm{km} / \mathrm{hr})\end{array}$} & \multirow{2}{*}{$\begin{array}{l}\text { Soil water } \\
\text { content }{ }^{1} \\
(\%)\end{array}$} & \multirow{2}{*}{$\begin{array}{c}\text { Fuel water } \\
\text { content } \\
(\%)\end{array}$} & \multicolumn{3}{|c|}{ Fuel load (kg/ha) } \\
\hline & & & & & & Litter & Standing & Total \\
\hline $\begin{array}{l}\text { Aug. } 1979 \\
\text { Feb. } 1980 \\
\text { Aug. } 1981 \\
\text { Feb. } 1982\end{array}$ & $\begin{array}{l}33 \\
12 \\
32 \\
31\end{array}$ & $\begin{array}{l}39 \\
52 \\
65 \\
20\end{array}$ & $\begin{array}{r}0-12 \\
0-11 \\
5-16 \\
13-20\end{array}$ & $\begin{array}{r}6-11 \\
13-10 \\
10-11 \\
13-16\end{array}$ & $\begin{array}{r}22 \\
12 \\
33 \\
8\end{array}$ & $\begin{array}{l}592 \\
630 \\
552 \\
852\end{array}$ & $\begin{array}{r}1782 \\
992 \\
3290 \\
1556\end{array}$ & $\begin{array}{l}2374 \\
1622 \\
3842 \\
2408\end{array}$ \\
\hline
\end{tabular}

ISoil water contents are averages of 6 samples from depths of 0 to 15 and 30 to $45 \mathrm{~cm}$, expressed on a dry weight basis.

the afternoon hours on 4 dates: 22 August 1979, 1 February 1980, 25 August 1981, and 17 February 1982. Fire lanes were established to a width of $4 \mathrm{~m}$ with a motor grader. Separate plots were burned on each date, and each plot was burned only once. Burns were conducted during water stress-induced dormancy of herbaceous vegetation in late summer and during winter dormancy, just before the onset of growth of herbaceous species in early spring. False broomweed, a drought-resistant, evergreen shrub, remains physiologically active in summer and winter.

Fine fuel loads were calculated from pre-burn determinations of herbaceous standing crop, as described later. Soil samples of 400 to $500 \mathrm{~g}$ each were collected from the upper $15 \mathrm{~cm}$ and at depths of 30 to $45 \mathrm{~cm}$ at 3 locations in each plot for gravimetric determination of water content just before burning. Samples of the fine fuel weighing about $25 \mathrm{~g}$ were clipped at 5 locations in each plot. Soil and fine fuel were weighed before and after drying at $60^{\circ} \mathrm{C}$ and water content was calculated on the dry weight basis. Temperature sensitive pellets ("tempils") were suspended at heights of 10 and $60 \mathrm{~cm}$ on steel posts at 2 locations in each plot to provide an estimate of maximum fire temperatures. Air temperature and relative humidity were recorded with a hygrothermograph, and wind speed was estimated with a ball-in-tube anemometer. A raingauge was maintained about $1.5 \mathrm{~km}$ from the site.

Three sets of paired 30-m line transects were permanently established in each plot during the days preceding burning. Transect pairs were positioned by locating the first of each pair through a representative portion of the false broomweed stand, such that foliar interception of the shrub approached $50 \%$. The second line was placed parallel and adjacent to the first, at a distance of $4 \mathrm{~m}$. Foliar cover of false broomweed was recorded as live canopy interception along the first transect of each pair on the day before burning and again near the end of the growing season (August, September, or October) in each year for 4 years after burning. At the same times, standing crop by species and litter were harvested to a height of $1 \mathrm{~cm}$ from five $1-\mathrm{m}^{2}$ quadrats placed at points equally spaced along the second transect in each pair. Quadrats were rotated about the points annually so that the same herbaceous plants were not clipped repeatedly. Clipping samples and litter were oven dried, weighed, and converted to $\mathrm{kg} / \mathrm{ha}$. Species present in the clipped quadrats were recorded so that changes in frequency of occurrence could be detected. Frequency and standing crop of herbaceous species were sampled in the same manner on an unburned plot during the course of the study.

\section{Statiatical Analyses}

Foliar cover of false broomweed was analyzed as the percent decrease relative to the pre-burn cover. Data were subjected to analysis of variance with subsamples (transects) (Steel and Torrie 1980), by year after burning. Treatment effects were assigned to individual burn dates because of considerable variation in response to burns conducted in the same month of different years. The data were transformed to the arcsin of the square root prior to analysis, but transformation did not reduce the error mean square. Means were separated with Duncan's multiple range test.

Responses of herbaceous species were compared to pre-burn conditions rather than the unburned because of inherent differen- ces in species composition between plots burned in August and those not burned or burned in February. Data from the 2 burns in the same month of different years were pooled prior to analysis. Frequency of occurrence of major grasses by species and all forbs as a group in each year following burning was compared with that of the pre-burn evaluation with the chi-square test. Chi-square values for each year after burning, unadjusted for continuity, were totaled to provide a comparison of pre-burn frequency with that of the entire 4-year period following burning (Steel and Torrie 1980). Analyses of variance of standing crop were conducted by individual species and groups of species, with the 5 quadrats associated with each transect summed to provide a single datum. The 3 transects in each replicate plot were considered subsamples. Treatment effects were assigned to month of burning, and postburn evalutions were compared with the pre-burn standing crop with paired $t$-tests.

\section{Results and Discussion}

Weather and fuel conditions varied widely on the 4 dates when burns were conducted (Table 1). Air temperatures were high during all burns except those applied in February 1980. Wind speeds were lower than desired in August 1979 and February 1980. Water content of the fine fuel was especially variable, ranging from only $7 \%$ in February 1982 to $33 \%$ in August 1981 . The deleterious effect of the high water content of the fine fuel in August 1981 was partially offset by a high fuel load. Only $992 \mathrm{~kg} / \mathrm{ha}$ of standing fuel was available in February 1980. Maximum fire temperatures indicated by the tempils were very low at $150^{\circ} \mathrm{C}$ at $10 \mathrm{~cm}$ and $93^{\circ} \mathrm{C}$ at $60 \mathrm{~cm}$ because of the low fuel load and lack of steady winds in February 1980 . However, all burns were relatively cool in comparison with other controlled burns on the Rio Grande Plains (Stinson and Wright 1969). Maximum temperatures at $10 \mathrm{~cm}$ during the other 3 burns were 260 to $316^{\circ} \mathrm{C}$. At a height of $60 \mathrm{~cm}$, temperatures reached $316^{\circ} \mathrm{C}$ in August 1981 , but were only 150 to $260^{\circ} \mathrm{C}$ in August 1979 and February 1982, depending upon location of the steel post supporting the tempils. Estimates of the proportion of plot areas burned were $90 \%$ or more in August 1979 and 1981 and between 80 and $90 \%$ in February 1980 and 1982.

\section{Falue Broomweed Response}

The reduction in foliar cover of false broomweed, relative to preburn foliar cover, varied from 77 to $36 \%$ at 1 year after treat-

Table 2. Percent decrease in foliar cover of false broomweed 1 to 4 years after controlled buming on four dates near Bateaville, Texas.

\begin{tabular}{lcccc}
\hline & \multicolumn{4}{c}{ Year after burning 1} \\
\cline { 2 - 5 } Burn date & 1 & 2 & 3 & 4 \\
\hline Aug. 1979 & $65 \mathrm{~b}$ & $45 \mathrm{~b}$ & $37 \mathrm{ab}$ & $34 \mathrm{~b}$ \\
Feb. 1980 & $77 \mathrm{~b}$ & $69 \mathrm{c}$ & $61 \mathrm{~b}$ & $54 \mathrm{c}$ \\
Aug. 1981 & $45 \mathrm{a}$ & $42 \mathrm{~b}$ & $42 \mathrm{ab}$ & $24 \mathrm{~b}$ \\
Feb. 1982 & $36 \mathrm{a}$ & $25 \mathrm{a}$ & $24 \mathrm{a}$ & $3 \mathrm{a}$ \\
\hline
\end{tabular}

IMeans within a column followed by the same letter do not differ significantly at the 95\% level according to Duncan's multiple range test. 
ment (Table 2). Burn conditions such as fuel load and fire temperatures were not reflected in the response of false broomweed. Season of burning appeared to have little influence on the effectiveness of fire for suppressing false broomweed; summer burns were not uniformly more effective, as has been demonstrated with other brush species (Scifres 1980). Decreases in foliar cover did not differ significantly 1 year after the August 1979 and February 1980 burns were applied, not did they differ significantly 1 year after.burns were applied in August 1981 and February 1982. Burns applied in 1981 and 1982 were considerably less effective than those applied in 1979 and 1980, but no reason for this was apparent.

Resprouting and regrowth replaced foliar cover to some extent in plots burned on all dates during the second, third, and fourth growing seasons (Table 2). Reductions in foliar cover varied widely with burn date at the end of the fourth growing season. Less than half of the original topgrowth was replaced over the 4-year period in plots burned in February 1980, while false broomweed had almost completely recovered in plots burned in February 1982 . The reduction in false broomweed foliar cover was almost $30 \%$ after 4 years when averaged over all burn dates.

\section{Frequency of Occurrence of Herbaceous Species}

Frequency of the most common grasses in the unburned control was relatively uniform over the entire sampling period, 1979 to 1985 (data not shown). Few significant changes in frequency were apparent in the burned plots. Commonly curlymesquite was

Table 3. Frequency of occurrence (\%) of major grass species and all forbs Immediately before (year 0 ) and 1 to 4 years after controlled burning in Auguat 1979 and 1981 near Batesville, Texas. Sums of the unadjusted $\chi^{2} 3$ across all years after burning are fiven for comparison of frequency during the entire post-burn period with the preburn frequency.

\begin{tabular}{lcccccc}
\hline & \multicolumn{7}{c}{ Year after burningl } & \\
\cline { 2 - 6 } Species & 0 & 1 & 2 & 3 & 4 & $\chi^{2}$ \\
\hline Common curlymesquite & 28 & 43 & 38 & 43 & 47 & $11.5^{*}$ \\
Pappusgrasses & 87 & 75 & 77 & 88 & 78 & 2.5 \\
Texas bristlegrass & 60 & 65 & 55 & 52 & 63 & 3.4 \\
White tridens & 12 & $38^{*}$ & 18 & 18 & 22 & $19.6^{* *}$ \\
Two-flower trichloris & 15 & 22 & 25 & 15 & 22 & 3.7 \\
King Ranch bluestem & 9 & 13 & 13 & 12 & 15 & 8.1 \\
Hall's panicum & 7 & $23^{* *}$ & $28^{* *}$ & $18^{*}$ & $20^{*}$ & $31.4^{* *}$ \\
Purple threeawn & 13 & 12 & 17 & 22 & 17 & 7.4 \\
Red grama & 35 & $13^{* *}$ & $8^{* *}$ & $7^{* *}$ & $10^{* *}$ & $45.6^{* *}$ \\
Whorled dropseed & 23 & 18 & 15 & 15 & 15 & $10.8^{*}$ \\
Forbs & 60 & 58 & 58 & 65 & 73 & 2.5 \\
\hline
\end{tabular}

'A single asterisk indicates that the post-burn frequency is significantly different from the preburn frequency at the $95 \%$ level according to $\chi^{2}$. Two asterisks denote significance at the $99 \%$ level.

slightly but not significantly more frequent each year after burning in August (Table 3), although its initial frequency in plots burned in August was relatively low in comparison with those burned in February (Table 4) and in the unburned control. Although common curlymesquite frequencies did not differ when individual years were compared with the August preburn sampling, the sum of chi-squares across post-treatment evaluations differed from the preburn frequency at the $5 \%$ level. Frequency of common curlymesquite was less affected by burning in February.

Pink and whiplash pappusgrasses were encountered in about twice as many quadrats in plots burned in August (Table 3) as in plots burned in February (Table 4), before and after burning. Occurrence of pappusgrasses and most other midgrasses was not greatly affected by burning in either season. However, white tridens was considerably more abundant during the first growing season after burning in August (Table 3) and in the second and fourth growing seasons after burning in February (Table 4). Burning in either month favored white tridens to some extent for at least 4 years. Frequency of Hall's panicum more than doubled following
Table 4. Frequency of occurrence (\%) of major grass species and all forbs immedintely before (year 0 ) and 1 to 4 years after controlled burning in February 1980 and 1982 near Batesville, Texas. Sums of the unadjusted $\chi^{2}$ 's across all years after burning are given for comparison of frequency during the entire post-bum period with the preburn frequency.

\begin{tabular}{lcccccc}
\hline \hline & \multicolumn{6}{c}{ Year after burning } \\
\cline { 2 - 6 } Species & 0 & 1 & 2 & 3 & 4 & $\chi^{2}$ \\
\hline Common curlymesquite & 72 & 83 & 82 & 85 & 90 & 4.0 \\
Pappusgrasses & 42 & 38 & 48 & 42 & 57 & 2.9 \\
Texas bristlegrass & 48 & 57 & 37 & $22^{*}$ & 32 & $15.4^{* *}$ \\
White tridens & 5 & 17 & $23^{* *}$ & 18 & $22^{*}$ & $24.9^{* *}$ \\
Two-flower trichloris & 3 & 3 & 5 & 0 & 0 & 4.3 \\
King Ranch bluestem & 9 & 10 & 12 & 3 & 3 & 2.7 \\
Hall's panicum & 20 & $12^{*}$ & 17 & $8^{*}$ & $5^{*}$ & $23.8^{* *}$ \\
Purple threeawn & 20 & 10 & 23 & 23 & 18 & 2.8 \\
Red grama & 28 & 10 & 10 & $8 *$ & $7^{*}$ & $22.9^{* *}$ \\
Whorled dropseed & 13 & 13 & 10 & 12 & 10 & 0.7 \\
Forbs & 18 & $43^{* *}$ & $58^{* *}$ & $47^{* *}$ & $65^{* *}$ & $81.3^{* *}$ \\
\hline
\end{tabular}

'A single asterisk indicates that the post-burn frequency is significantly different from the preburn frequency at the $95 \%$ level according to the $\chi^{2}$ test. Two asterisks denote significance at the $99 \%$ level.

August burns and slightly decreased after burning in February. Texas bristlegrass was less abundant at the end of the third growing season after burning in February.

Red grama, 1 of 3 perennial species of low forage value which were common on the site, responded negatively to burning in August or February. Purple threeawn was unaffected by burning in August. Burning in February decreased abundance of purple theeeawn during the first post-burn growing season, although this temporary decrease was not statistically significant (Table 4). Abundance of whorled dropseed was slightly suppressed in all years after burning in August but not in February.

Frequency of occurrence of forbs was fairly uniform over time in plots burned in August (Table 3). Occurrence of forbs appeared to increase dramatically after burning in February (Table 4), but this response was attributed to the comparison of post-treatment sampling at the end of the growing season, when forbs were common, to pre-treatment sampling in February, when many species of annual broadleafed plants were not in evidence.

Standing Crop of Herbaceous Species

Standing crop of grasses and forbs varied widely in the unburned area over the course of the study (Table 5). Standing crop of

Table 5. Oven-dry standing crop (kg/ha) of principal grass species, groups of grases, all forbs, and litter on the unburned plot on dates when controlled burns were sampled near Batesville, Texas.

\begin{tabular}{lrrrrrrr}
\hline \hline & \multicolumn{7}{c}{ Sampling dates } \\
\cline { 2 - 8 } Species or group & Aug. & Oct. & Aug. & Sept. & Aug. & Oct. & Oct. \\
& 1979 & 1980 & 1981 & 1982 & 1983 & 1984 & 1985 \\
\hline Common curlymesquite & 616 & 311 & 1010 & 437 & 222 & 608 & 514 \\
Pappusgrasses & 313 & 211 & 279 & 202 & 238 & 217 & 194 \\
Texas bristlegrass & 148 & 344 & 172 & 196 & 126 & 151 & 54 \\
White tridens & 49 & 140 & 209 & 66 & 25 & 61 & 0 \\
Two-flower trichloris & 65 & 132 & 97 & 54 & 105 & 60 & 28 \\
King Ranch bluestem & 10 & 28 & 45 & 12 & 2 & 0 & 0 \\
Hall's panicum & 1 & 1 & 1 & 37 & 1 & 0 & 5 \\
All bunchgrasses & 585 & 856 & 803 & 567 & 497 & 489 & 281 \\
Purple threeawn & 16 & 4 & 69 & 17 & 8 & 0 & 46 \\
Red grama & 146 & 129 & 126 & 229 & 97 & 56 & 16 \\
Whorled dropseed & 22 & 18 & 2 & 28 & 40 & 1 & 8 \\
All minor grasses & 184 & 151 & 198 & 349 & 146 & 60 & 61 \\
All grasses & 1386 & 1318 & 2011 & 1353 & 865 & 1157 & 856 \\
All forbs & 55 & 28 & 32 & 4 & 12 & 15 & 30 \\
Litter & 580 & 287 & 352 & 407 & 175 & 100 & 305 \\
\hline
\end{tabular}


common curlymesquite was especially variable, ranging from a low of $222 \mathrm{~kg} / \mathrm{ha}$ in 1983 to $1,010 \mathrm{~kg} / \mathrm{ha}$ in 1981 . No reason was apparent for the low standing crop in 1983, but other variation was probably attributed to timing and amounts of rainfall. For instance, end-of-season standing crop of common curlymesquite in 1980 was only $311 \mathrm{~kg} / \mathrm{ha}$, and total rainfall during the 12-month period prior to sampling in 1980 was only $35 \mathrm{~cm}$ (Table 6), with almost no rain recorded from February to August. A total of $65 \mathrm{~cm}$ was recorded during the 12 months preceding sampling in 1981 , when standing crop was highest. Rainfall was also well below normal in 1982, again with a total of $35 \mathrm{~cm}$ recorded in the 12 months prior to sampling in September.

Table 6. Cumulative rainfall during the 12-month period prior to sampling controlled burns near Batesville, Texas.

\begin{tabular}{lc}
\hline \hline 12-month period & $\begin{array}{c}\text { Rainfall } \\
\text { (cm) }\end{array}$ \\
\hline Nov. 1979 to Oct. 1980 & 35 \\
Sep. 1980 to Aug. 1981 & 65 \\
Oct. 1981 to Sep. 1982 & 35 \\
Sep. 1982 to Aug. 1983 & 50 \\
Nov. 1983 to Oct. 1984 & 23 \\
Nov. 1984 to Oct. 1985 & 54 \\
\hline
\end{tabular}

Burning in August had little effect on standing crop of common curlymesquite when averaged across both summer burns (Table 7). A decrease in standing crop during the first growing season after burning was expected because of the drought conditions that prevailed after burning in August of 1979 and 1981 . Standing crop of common curlymesquite was low in the unburned control in 1980 (the first growing season after burning in 1979) and 1982 through 1983 (the first and second growing seasons after burning in 1981) (Table 5).

Standing crop of pappusgrasses was suppressed by burning in August (Table 7). Pappusgrass production was reduced from 1,322 $\mathrm{kg} / \mathrm{ha}$ before burning to only $342 \mathrm{~kg} / \mathrm{ha}$ at the end of the first growing season. Pappusgrass standing crop partially recovered during the second and third growing seasons, but was again significantly lower than the preburn standing crop at 4 years after burning, when rainfall was limited. Drought conditions during the first

Table 7. Oven-dry standing crop (kg/ha) of principal grass species, all forbs, and litter immediately before (year 0 ) and 1 to 4 years after controlled burning in Augut 1979 and 1981 near Batesville, Texas.

\begin{tabular}{lrrrrr}
\hline \hline & \multicolumn{5}{c}{ Year after burning } \\
\cline { 2 - 6 } Species or group & \multicolumn{1}{c}{1} & 1 & 2 & 3 & 4 \\
\hline Common curlymesquite & 318 & 325 & 448 & 434 & 335 \\
Pappusgrasses & 1322 & $342^{* *}$ & 963 & 1048 & $500^{* *}$ \\
Texas bristlegrass & 529 & 338 & 315 & 426 & $161^{*}$ \\
White tridens & 18 & $204^{* *}$ & $74^{*}$ & $57^{*}$ & $60^{*}$ \\
Two-flower trichloris & 45 & 52 & 60 & 86 & 50 \\
King Ranch bluestem & 84 & 66 & 80 & 49 & $14^{*}$ \\
Hall's panicum & 18 & 20 & $59 *$ & 43 & 14 \\
All bunchgrasses & 2016 & $1022^{*}$ & 1551 & 1709 & $799^{*}$ \\
Purple threeawn & 13 & $29 *$ & 20 & 12 & 12 \\
Red grama & 44 & $3^{* *}$ & $10^{* *}$ & $3^{* *}$ & $7^{* *}$ \\
Whorled dropseed & 38 & $8^{* *}$ & $11^{* *}$ & $1 * *$ & $9 * *$ \\
All minor grasses & 85 & $40^{*}$ & $41^{*}$ & $16^{* *}$ & $28^{*}$ \\
All grasses & 2419 & $1387^{*}$ & 2040 & 2159 & $1162^{*}$ \\
All forbs & 91 & 48 & 168 & 58 & 38 \\
Litter & 572 & $102^{* *}$ & $285^{* *}$ & 550 & 555 \\
\hline A single asteris & & & & &
\end{tabular}

IA single asterisk indicates that the post-burn standing crop is significantly different from the preburn standing crop at the $95 \%$ level according to paired $t$-tests. Two asterisks denote significance at the $99 \%$ level. growing seasons after burning in August 1979 and 1981 may also have contributed to the temporary reduction in standing crop of this species. Standing crop of Texas bristlegrass was lower than the preburn level in each year after burning in August, but differences were not significant until the fourth year. Conversely, burning greatly promoted productivity of white tridens, especially in the first post-burn year, as observed with frequency of occurrence. Hall's panicum was most productive in the second and third years after burning, while standing crop of two-flower trichloris and King Ranch bluestem remained unaffected. Standing crop of all bunchgrasses was about half that of the preburn standing crop at the end of the first and fourth growing seasons following August burns.

Although purple threeawn was no more frequent following August burns (Table 3), standing crop was significantly higher at 1 year and tended to be higher at 2 years after burning (Table 7). Standing crop of red grama and whorled dropseed was substantially reduced in each year following summer burns, as would be expected in view of the decreases in frequency. These responses were reflected in the total standing crop of the 3 undesirable bunchgrasses, which was reduced to half or less of the preburn standing crop in each year.

Total production of all grasses in plots burned in August fell from $2,419 \mathrm{~kg} /$ ha before burning to $1,387 \mathrm{~kg} / \mathrm{ha}$ about 1 year after burning (Table 7), a significant decrease of over $1,000 \mathrm{~kg} / \mathrm{ha}$. Losses in the second and third years were about 400 and $300 \mathrm{~kg} / \mathrm{ha}$, respectively. In each of these years, the decrease in total grass production relative to the preburn sampling was essentially equal to the decrease in standing crop of pappusgrasses.

Forb standing crop in plots burned in August was highly variable and apparently associated with rainfall. An average of $\mathbf{5 7 2}$ $\mathrm{kg} / \mathrm{ha}$ of litter occurred on plots immediately before burning in August (Table 7). Almost all of this was consumed by the fires, and a total of $102 \mathrm{~kg} /$ ha accumulated during the following growing season. Despite relatively poor growing conditions due to limited rainfall, only 3 years were required for litter accumulation to completely replace that harvested just before burning.

Buming in February had little effect on standing crop of common curlymesquite (Table 8). Production of desirable bunchgrasses was much less on plots burned in February 1980 and 1981 than on plots burned in August. In general, the responses of bunchgrasses to burning in February and August were similar. Standing crop of pappusgrasses was suppressed during the growing season following burning, recovered during the second and

Table 8. Oven-dry standing crop (kg/ha) of principal grass species, all forbs, and litter Immediately before (year 0 ) and 1 to 4 years after controlled burning in February 1980 and 1982 near Batesville, Texas.

\begin{tabular}{lrrrrr}
\hline \hline & \multicolumn{5}{c}{ Year after burning } \\
\cline { 2 - 6 } Species or group & 0 & 1 & 2 & 3 & 4 \\
\hline Common curlymesquite & 714 & 597 & 1066 & 850 & 694 \\
Pappusgrasses & 212 & $87^{*}$ & 287 & 212 & $113^{*}$ \\
Texas bristlegrass & 150 & 106 & 135 & $42^{* *}$ & $36^{* *}$ \\
White tridens & 40 & 40 & $112^{* *}$ & 42 & 40 \\
Two-flower trichloris & 4 & 3 & 6 & 0 & 0 \\
King Ranch bluestem & 51 & 57 & $29^{*}$ & $6^{* *}$ & $2^{* *}$ \\
Hall's panicum & 15 & $27^{*}$ & $29^{*}$ & $6^{*}$ & $2^{*}$ \\
All bunchgrasses & 472 & 320 & 598 & 374 & $236^{*}$ \\
Purple threeawn & 38 & $16^{* *}$ & $18^{* *}$ & $22^{*}$ & $11^{* *}$ \\
Red grama & 22 & $8^{* *}$ & $8^{* *}$ & $9 * *$ & $5^{* *}$ \\
Whorled dropseed & 6 & 5 & 2 & 1 & 6 \\
All minor grasses & 86 & $31^{* *}$ & $41^{* *}$ & $48^{* *}$ & $23^{* *}$ \\
All grasses & 1262 & 948 & 1705 & 1272 & 953 \\
All forbs & 17 & 28 & $53^{* *}$ & 30 & $40^{*}$ \\
Litter & 626 & $42^{* *}$ & $183^{* *}$ & 527 & 552 \\
\hline A single asterisk indicates & & & & &
\end{tabular}

IA single asterisk indicates that the post-burn standing crop is significantly different from the preburn standing crop at the $95 \%$ level according to paired t-tests. Two asterisks denote significance at the $99 \%$ level. 
third growing seasons, and was again significantly less in the fourth year (Table 8).

Standing crop of purple threeawn and red grama was significantly less in all 4 years after burning in February. Total standing crop of these small, weak perennials was about half the preburn standing crop in the years after burning in February, as occurred after burning in August. Forbs appeared to be more productive after burning, but this response was probably caused by the comparison of post-treatment samplings in August to the preburn sampling in February, as with frequency of occurrence. Species composition and productivity of forbs were probably unaffected by fire in either season, in contrast to reports of other research in south Texas (Box et al. 1967, Box and White 1969, Gordon and Scifres 1977). Standing crop of litter was replaced by the end of the third growing season after the February burns, as in plots burned in August, suggesting that burning could be repeated on these rolling hardland sites as often as every 3 or 4 years.

Standing crop of the less productive grasses such as red grama was decreased by fire, a response that is largely positive by virtue of their lack of importance as forage for livestock or food for wildlife. Substantial decreases in frequency of occurrence of red grama and whorled dropseed, especially after August burns, indicate that reductions in standing crop of these weak perennials occurred because individuals were killed by the fires and not replaced by establishment of new seedlings in subsequent years.

The reduction in standing crop of the predominant bunchgrasses, pink and whiplash pappusgrasses, must be viewed as a negative response. The loss in yield of these species was temporary, occurring in the first growing season after burning in February or August. The lack of comparable changes in frequency of occurrence of pappusgrasses would suggest that decreases in standing crop were caused by low productivity of surviving plants, rather than a decrease in the number of individuals. Decreases in pappusgrasses standing crop in the fourth year paralleled decreases in standing crop of other species, and may have been caused by drought in those years. The confounding influence of continued protection from grazing and associated decadence of the herbaceous plants may have become apparent at the later evaluation.

\section{Conclusions}

Although the reductions in foliar cover varied widely among burn dates, reductions in the shrub's competitive potential of up to $50 \%$ after 4 years suggest that fire has value as a management practice for rangeland dominated by false broomweed. Reductions in foliar cover for several years appeared to be a result of mortality and a relatively slow rate of regrowth of plants surviving the fires. Mortality was not quantitatively determined, but visual observations indicated that about one-third of the shrubs burned in 1979 and 1980 failed to resprout, while mortality in plots burned in 1981 and 1982 appeared to be less than a third.

Burning false broomweed-infested rangeland near Batesville in either season did not increase forage standing crop, but comparisons of standing crop of individual species before and after burning suggest that fire altered the composition of the herbaceous standing crop. The adverse effect of fire on pappusgrasses, the most common and productive species on plots burned in August, caused substantial decreases in total standing crop of forage during the first growing season after treatment. The decrease in total production after burning in February was slight, but it might have been equal to that in August burns if pappusgrasses had contributed a larger proportion of the pre-burn standing crop. Plots burned in Feburary were dominated by the stoloniferous common curlymesquite, which was neither damaged nor favored to an appreciable extent by fire, even when recovery was limited by inadequate rainfall.

Controlled or prescribed burning increased forage standing crop (Box et al. 1967, Box and White 1969, Gordon and Scifres 1977, Scifres and Kelley 1979) and improved species composition of the grass component (Box and White 1969, Mutz et al. 1985, Scifres and Kelley 1979) in other research in south Texas, especially when burns were conducted in winter or early spring in years with adequate rainfall. Exceptions have been noted, such as the supression of gulf cordgrass [Spartina spartinae (Trin.) Hitchc.] production following a burn in June (McAtee et al. 1979). However, these studies were conducted in the eastern Rio Grande Plains and Coastal Prairies, where average annual rainfall is higher, rainfall following burning is more dependable, and the herbaceous species differ from those of the northwestern Rio Grande Plains. Burning buffelgrass in late winter reduced production when followed by a dry spring and summer in the southwestern portion of the Rio Grande Plains, where average annual rainfall is $50 \mathrm{~cm}$ (Hamilton and Scifres 1982).

Fire may be more useful in management of false broomweed in the more mesic eastern portion of the Rio Grande Plains and adjacent Coastal Prairies, where the shrub frequently occurs in dense stands. A burn applied in February 1979 near the Gulf coast, about $400 \mathrm{~km}$ southeast of the Batesville site, killed almost $50 \%$ of the false broomweeds and severely reduced foliar cover for several years. ${ }^{1}$ Fuel conditions created intense fires, with fine fuel loads ranging from 3,700 to $5,185 \mathrm{~kg} /$ ha. Grass standing crop was $15 \%$ greater and forb standing crop was $71 \%$ greater in the burned area than in an adjacent unburned area at the end of the first growing season after burning. Forage quality of grasses was also significantly higher during most of the 1979 growing season (Everitt and Mayeux 1983).

Unpublished data provided by J.H. Everitt, USDA, Agricultural Research Service, Weslaco, Texas 78596 .

\section{Literature Cited}

Box, T.W., J. Powell, and D.L. Drawe. 1967. Influence of fire on south Texas chaparral communities. Ecology 48:955-961.

Box, T.W., and R.S. White. 1969. Fall and winter burning of south Texas brush ranges. J. Range Manage. 22:373-376.

Evertt, J.H., and H.S. Mayeux, Jr. 1983. Nutritive contents of two grasses and one browse species following rangeland burning in south Texas. Southwest. Natur. 28:242-244.

Gordon, R.A., and C.J. Seifres. 1977. Burning for improvement of Macartney rose-infested coastal prairic. Texas Agr. Exp. Sta. Bull. 1183.

Hamilton, W.T., and C.J. Selfres. 1982. Prescribed burning during winter for maintenance of buffelgrass. J. Range Manage. 35:9-12.

Mayeux, H.S., Jr., and A.D. Chamrad. 1982. Response of false broomweed (Ericameria austrotexana) and associated herbaceous vegetation to pelleted herbicides. Weed Sci. 30:668-671.

Mayeux, H.S., Jr., and W.T. Hamilton. 1993. Response of common goldenweed (Isocoma coronopifolia) and buffelgrass (Cenchrus ciliaris) to fire and soil-applied herbicides. Weed Sci. 31:355-360.

Mayeux, H.S., Jr., C.J. Scifres, and R.A. Crane. 1990. Ericameria austrotexana and associated range forage response to herbicides. Weed Sci. 28:602-606.

McAtee, J.W., C.J. Setfres, and D.L. Drawe. 1979. Improvement of gulf cord grass range with burning or shredding. J. Range Manage. 32:372-375.

Mutz, J.L., T.G. Green, C.J. Seffres, and B.H. Koerth. 1985. Response of Pan American balsamscale, soil, and livestock to prescribed burning. Texas Agr. Exp. Sta. Bull. 1492.

Selfres, C.J. 1980. Brush management. Principles and practices for Texas and the Southwest. Texas A\&M Univ. Press, College Station.

Scifres, C.J., and D.M. Kelley. 1979. Range vegetation response to burning thicketized live oak savannah. Texas Agr. Exp. Sta. Bull. 1246.

Steel, R.G.D., and J.H. Torrie. 1980. Principles and procedures of statistics. McGraw-Hill Book Co., New York, N.Y.

Stinson, J.J., and H.A. Writht. 1969. Temperatures of head fires in the southern mixed prairie of Texas. J. Range Manage. 22:169-174.

Ueckert, D.N., S.G. Whicenant, and G.W Sultemeler. 1983. Control of rayless goldenrod (Isocoma wrightii) with soil-applied herbicides. Weed Sci. 31:143-147.

Vogl, R.J. 1974. Effects of fire on grasslands. P. 139-194. In: T.T. Kozlowski and C.E. Ahlgren, eds. Fire and Ecosystems. Academic Press, New York. N.Y.

Wright, H.A., and A.W. Balley. 1982. Fire ecology, United States and Southern Canada. John Wiley and Sons, new York, N.Y. 